\title{
Investigation on the Intensity Attenuation Speed of the Single-Charged Ionized Vapor and Neutral Vapor at Current Chopping in Vacuum Arc
}

\author{
Teruo YamamotoＳtudent Member (Tokyo Denki University, 04gme28@ed.cck.dendai.ac.jp) \\ Cuie Ding Student Member (Tokyo Denki University) \\ Mijit Tursun Student Member (Tokyo Denki University) \\ Satoru Yanabu Member (Tokyo Denki University)
}

Keywords: low current vacuum arc, chopping current, spectrum intensity, ionized vapor, neutral vapor, electrode material

\section{Introduction}

In order to clarify the instability phenomena of a low current in the vacuum, the optical characteristics of a low current vacuum arc was investigated by using $\mathrm{Cu}, \mathrm{CuW}, \mathrm{CuCr}, \mathrm{CuBi}$, and $\mathrm{AgWC}$ electrodes.

At the time of current chopping, the spectrum intensity of neutral vapor wavelength (Ucn), single-charged ionized vapor wavelength (Uci) and its attenuation speed (dUcn/dt), as well chopping current (Ic) were measured in the current zero waveform, as show in Fig. 1.

\section{Experimental results and discussion}

Table 1 shows the results of electrode materials in the parameter shown in Fig. 1.

The attenuation speed of spectrum intensity of the neutral vapor (dUcn/dt) when the current chopping is the fastest in the $\mathrm{Cu}$ electrode material as shown in Table 1. That is, the amount of metal vapor generated from the electrode is the smallest, and the diffusion speed is fastest. It is thought that metal vapor necessary to maintain a steady arc discharge is insufficient, and the chopping current grew

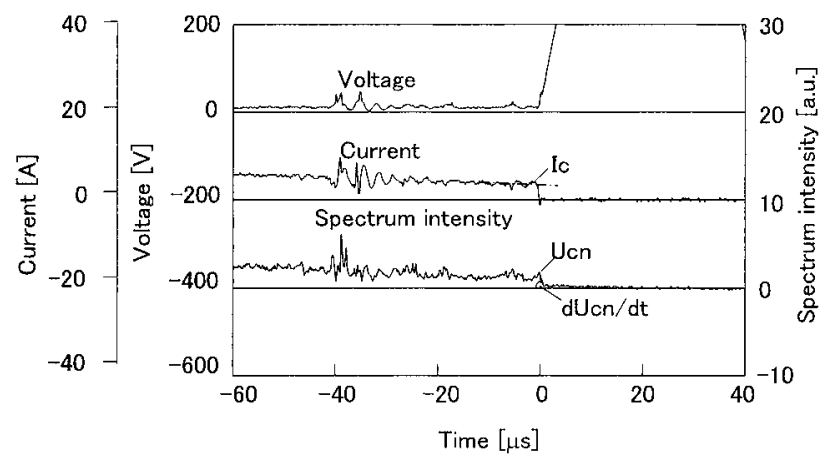

Fig. 1. Current zero waveform of $\mathrm{Cu}$ neutral vapor at $\mathrm{CuW}$ electrode
Table 1. Spectrum intensity and attenuation speed of intensity

\begin{tabular}{|c|c|c|c|c|}
\hline Material & Ic $[A]$ & $\begin{array}{l}\text { Ucn } \\
\text { [a.u.] }\end{array}$ & $\begin{array}{l}\mathrm{dU} \mathrm{cn} / \mathrm{dt} \\
\text { [a.u. } / \mu \mathrm{s}]\end{array}$ & $\begin{array}{c}\text { Uci } \\
\text { [a.u.] }\end{array}$ \\
\hline $\begin{array}{l}\mathrm{Ag} \text { in } \mathrm{AgWC} \\
W \text { in } A g W C\end{array}$ & 1.7 & $\begin{array}{l}0.9 \\
0.7\end{array}$ & $\begin{array}{l}1.1 \\
0.7\end{array}$ & $\begin{array}{l}0.1 \\
0.1\end{array}$ \\
\hline $\mathrm{Cu}$ in $\mathrm{CuBi}$ & 4.0 & 2.1 & 1.6 & 0.2 \\
\hline $\begin{array}{l}\mathrm{Cu} \text { in } \mathrm{CuCr} \\
\mathrm{Cr} \text { in } \mathrm{CuCr}\end{array}$ & 4.6 & $\begin{array}{l}2.2 \\
6.8\end{array}$ & $\begin{array}{r}2.3 \\
11.4\end{array}$ & $\begin{array}{l}0.4 \\
0.7\end{array}$ \\
\hline $\begin{array}{l}\text { Cu in CuW } \\
W \text { in CuW }\end{array}$ & 4.9 & $\begin{array}{l}5.9 \\
3.2\end{array}$ & $\begin{array}{l}6.7 \\
2.9\end{array}$ & $\begin{array}{l}0.4 \\
0.1\end{array}$ \\
\hline $\mathrm{Cu}$ in $\mathrm{Cu}$ & 10.7 & 36.9 & 55.0 & 0.8 \\
\hline
\end{tabular}

Spectrum intensity: Ucn (Neutral), Uci (Ion) Attenuation speed: dUcn/dt (Neutral)

before the current decreases from this, and it becomes natural zero.

Like a CuW electrode, when the current approaches a zero from the particularly high boiling point and low vapor pressure for the same temperature of $\mathrm{W}$, the evaporation of $\mathrm{W}$ is very mall and can ignore it. As for this, spectrum intensity attenuation speed of $\mathrm{Cu}$ influences chopping current, and it is thought that, furthermore, it is similar in an $\mathrm{AgWC}$ electrode.

From this, the attenuation speed of spectrum intensity $(\mathrm{dUcn} / \mathrm{dt})$ increase in order of $\mathrm{AgWC}, \mathrm{CuBi}, \mathrm{CuCr}, \mathrm{CuW}$ and $\mathrm{Cu}$. Moreover, Ic increases in same order of $\mathrm{AgWC}, \mathrm{CuBi}, \mathrm{CuCr}$, and $\mathrm{Cu}$, too.

We measured spectrum intensity (Ucn and Uci). In an electrode the same as both, it seems that it is difficult that we connect it with a chopping current every materials so that values are different greatly. 


\title{
真空アークの電流裁断における 1 価イオンおよび中性蒸気の 光強度減衰速度の研究
}

\author{
学生員 山本 晃生* 学生員 丁 翠娥* \\ 学生員 Mijit Tursun* 正 員 柳父 悟*
}

\author{
Investigation on the Intensity Attenuation Speed of the Single-Charged Ionized Vapor \\ and Neutral Vapor at Current Chopping in Vacuum Arc
}

Teruo Yamamoto*, Student Member, Cuie Ding*, Student Member,

Mijit Tursun*, Student Member, Satoru Yanabu*, Member

In order to clarify the instability phenomena of a low current in the vacuum, the optical characteristics of a low current vacuum arc was investigated by using $\mathrm{Cu}, \mathrm{CuW}, \mathrm{CuCr}, \mathrm{CuBi}$, and $\mathrm{AgWC}$ electrodes. We measured the spectrum-line intensity distribution against wavelength during arc discharge for each electrode. It was found that for $\mathrm{Cu}, \mathrm{CuW}$, $\mathrm{CuCr}, \mathrm{CuBi}$ and $\mathrm{AgWC}$ electrodes, the total amount of the spectrum intensity from $350 \mathrm{~nm}$ to $950 \mathrm{~nm}$ wavelength (SI) increases in the order of $\mathrm{Cu}, \mathrm{CuCr}, \mathrm{CuBi}, \mathrm{AgWC}$, and except for $\mathrm{CuW}$ the chopping current decrease in the same order.

For each component of every electrode material, the spectrum intensity and its attenuation speed of the neutral vapor at current chopping (Ucn, dUcn/dt) were investigated.

It was found that the attenuation speed at current chopping decreases in the order of $\mathrm{Cu}, \mathrm{CuW}, \mathrm{CuCr}, \mathrm{CuBi}$ and $\mathrm{AgWC}$, the chopping current decreases in the same order.

We will inspect the current chopping phenomena by observing the intensity change of the neutral vapor, and discuss relationship of electrode material and the chopping current from a new viewpoint of evaporation ability and the plasma decay speed.

キーワード：小電流真空アーク, 裁断電流, スペクトル強度, イオン蒸気, 中性蒸気, 電極材料

Keywords: low current vacuum arc, chopping current, spectrum intensity, ionized vapor, neutral vapor, electrode material

\section{1. まえがき}

真空中のアーク放電は，電極から放出されるイオン化さ れた金属蒸気や電子によって維持されていることから，アー ク放電の安定性は, 電極材料が蒸気を生成する能力や熱電 子を放出する能力と関係が深いものと考えられている。

小電流真空アーク中において, 電流がゼロに近づくとアー ク電流および電圧が不安定となり振動を起こし, 自然電流 零点前に電流が途絶える裁断現象が生じる。

この電流裁断現象は様々な接点材料により, 従来の研究 によって調査されている(1) (4)。

本件は，この小電流真空アーク放電中に発生する不安定 現象発生時の不安定開始電流 (Ib), 裁断電流 (Ic), アーク 電圧（Varc）, 振動電圧最大值（Vosmax）および再起電圧

\footnotetext{
*東京電機大学

厂 101-8457 東京都千代田区神田錦町 2-2

Tokyo Denki University

2-2, Nisikicho-Kanda, Chiyoda-ku, Tokyo 101-8457
}

最大值（Vremax）について，開閉装置に一般的に使用され ている $\mathrm{Cu}, \mathrm{CuCr}, \mathrm{CuW}$ および $\mathrm{AgWC} の 4$ 種類の電極を 用いて, 各種パラメータの測定を行った。そして, この結 果の電流および電圧の傾向は著者らの従来の研究 ${ }^{(5)}$ と同様 な結果が得られた。ここで，この波形解析から得られた裁 断電流值の傾向が電流および電圧の特性だけではなく, 光 学的特性と同様であるのかが重要となってくる。

そこで，同電極に CuBi を追加した 5 種類の電極を用い て, 裁断電流 (Ic) およびスペクトル分析の光学的測定か ら, 波長として $350 \mathrm{~nm} \sim 950 \mathrm{~nm}$ のスペクトル強度の総量 $(\mathrm{SI})$, アーク放電時での中性蒸気および 1 価のイオン発光 強度の最大值および変化速度の大きさ $(\mathrm{Umn}, \mathrm{dUmn} / \mathrm{dt}$, Umi， dUmi/dt）の測定を行った。

そして,さらに裁断電流值に直接関係する電流裁断時の 中性蒸気の光強度および減衰速度の大きさ $(\mathrm{Ucn}, \mathrm{dUcn} / \mathrm{dt})$ や紫外領域を主体とする 1 価のイオン蒸気の発光強度 (Uci) 測定を行った。この結果から光の減衰が蒸気の拡散と考え たため，拡散されることにより，放電が維持できなくなり， 
裁断されると考えられる。この結果は直接的な電流遮断現 象の基礎特性として重要な役割を担っていると考えられる。

\section{2. 不安定現象の波形解析}

$\langle 2 \cdot 1\rangle$ 実験回路 不安定現象の波形解析を行う実験 回路を図 1 に示す。回路において, 静電容量 $0.0654 \mathrm{~F}$ の コンデンサに電圧を充電させ，コンタクタのスイッチを投 入し，インダクタンス $0.157 \mathrm{mH}$ のリアクトルにより，約 $50 \mathrm{~Hz}$ の遮断電流を通電させる。通電中に電極を開極する ことにより発生したアークの電流，電圧をデジタルオシロ スコープにより検出し，その後コンピュータにより解析を 行った。遮断電流波高值 $600 \mathrm{~A}$ ，アーク放電時間を $5.2 \mathrm{~ms}$ 一定で放電させ実験を行った。充電電圧は $60 \mathrm{~V}$ とした。

$\langle\mathbf{2} \cdot 2\rangle$ 実験装置供試器である真空チャンバーにおい て，電極を上下に対向させ，空気圧により可動電極を垂直に 動かし開閉させる。ギャップの長さを $8 \mathrm{~mm}$ 一定とし, 平均 開極速度は約 $0.5 \mathrm{~m} / \mathrm{s}$ とした。電極材料は $\mathrm{Cu}, \mathrm{CuCr}(\mathrm{Cu}$ ： $50 \%), \mathrm{CuW}(\mathrm{Cu}: 26 \%)$ および $\mathrm{AgWC}(\mathrm{Ag}: 33 \%)$ の 4 種類で，電極直径はそれぞれ $20 \mathrm{~mm}$ である平板電極を用い て実験を行った。なお，真空チャンバーはロータリーポン プおよび油拡散ポンプにより，おおよそ $10^{-4} \mathrm{~Pa}$ まで持続 的に排気し，実験に供している。

$\langle\mathbf{2} \cdot \mathbf{3}\rangle$ 測定結果 観測結果の一例波形を図 2 に示す。 図において，不安定となりアーク電圧の $15 \%$ 程度以上の振 幅の電圧振動が始まった時点 (a) の電流を不安定開始電流 $\mathrm{Ib}$ ，裁断電流を Ic，アーク電圧を Varc，振動電圧最大值を Vosmax，再起電圧最大值をVremax によってそれぞれ示 す。実験は並列のコンデンサの容量を変化させたときの各 種パラメータの測定を行った。

〈2·3・1〉 並列コンデンサの影響コンデンサを接続 し, 容量を 0 から $5 \mu \mathrm{F}$ まで変化させた。その時の各種パラ メー夕の变化を表 1 に示す。結果から明らかなように, Ib お よびV Varcは容量を変化させても一定の值を示した。Icは容 量の増加とともに増加し, Vosmax およびVremax は減少し た。そして, Ib, Ic, Varc, Vremax は AgWC, CuW, CuCr および $\mathrm{Cu}$ の順に值が増加し, Vosmax は CuW, AgWC, $\mathrm{CuCr}$ および $\mathrm{Cu}$ の順に増加傾向を示した。

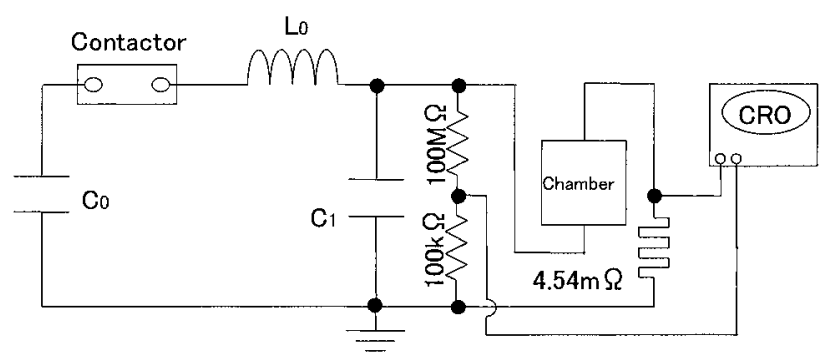

Co: Capacitance $(0.0654 \mathrm{~F})$, Lo: Inductance $(0.157 \mathrm{mH})$

C1: Capacitance $(0 \sim 5 \mu \mathrm{F}), \quad$ CRO: Oscilloscope

図 1 実験回路

Fig. 1. Experimental circuit.



図 2 電流零点近傍波形

Fig. 2. Waveform near current zero.

表 1 並列コンデンサの影響

Table 1. Effect of parallel capacitance $(\mathrm{C} 1=0 \rightarrow 5 \mu \mathrm{F})$.

\begin{tabular}{lrcccc}
\hline \hline Material & Ib $[\mathrm{A}]$ & Ic $[\mathrm{A}]$ & Varc $[\mathrm{V}]$ & Vosmax $[\mathrm{V}]$ & Vremax [V] \\
\hline $\mathrm{Cu}$ & 21.0 & $6.6 \rightarrow 11.0$ & 20.3 & $707.4 \rightarrow 212.6$ & $1829.2 \rightarrow 49.5$ \\
$\mathrm{CuCr}$ & 10.3 & $2.2 \rightarrow 5.5$ & 13.8 & $343.4 \rightarrow 119.6$ & $752.7 \rightarrow 28.0$ \\
$\mathrm{CuW}$ & 9.6 & $1.9 \rightarrow 3.2$ & 11.7 & $196.8 \rightarrow 18.0$ & $400.5 \rightarrow 25.7$ \\
$\mathrm{AgWC}$ & 7.4 & $0.9 \rightarrow 1.8$ & 10.7 & $180.9 \rightarrow 60.0$ & $198.1 \rightarrow 16.9$ \\
\hline
\end{tabular}

\section{3. 真空アークの光学的測定}

〈3・1〉 実験回路 光強度測定に使用した実験回路を図 3 に示す。回路において，商用電源より交流 $100 \mathrm{~V} / 50 \mathrm{~Hz}$ の 電圧を印加させ，限流リアクトルを調節することにより，遮 断電流波高值 $110 \mathrm{~A} ，$ アーク放電時間 $7.5 \mathrm{~ms}$ で放電させた。

$\langle\mathbf{3 \cdot 2}\rangle$ 実験装置供試器の条件は電極を除いて, 前 章と同様であり，電極材料は $\mathrm{Cu}, \mathrm{CuCr}(\mathrm{Cu}: 50 \%), \mathrm{CuW}$ $(\mathrm{Cu}: 26 \%), \mathrm{CuBi}(\mathrm{Cu}: 99 \%)$ および $\mathrm{AgWC}(\mathrm{Ag}: 33 \%)$ の 5 種類で，電極直径はそれぞれ $20 \mathrm{~mm}$ の平板電極を使用 した。

$\langle\mathbf{3} \cdot \mathbf{3}\rangle$ 光観測装置 アークの発光強度は, 図 4 に示す ように，放電によって放出された光は真空チャンバーの空 を通過し, 集光レンズにより集光させたのち, スペクトル測 定器 (MPM-C7460/HAMAMATSU $(350 \mathrm{~nm} \sim 950 \mathrm{~nm}$ のス ペクトル強度測定)）およびモノクロメータ (MO6978MN/ 溝尻光学工業所 (中性光測定), G-250/Nikon（イオン光測 定)）によって測定を行った。また，紫外光測定を行うため 石英空および石英レンズを使用し，光がレンズにより遮光 されないようにした。光電子増倍管を使うことによりモノ クロメータからの光信号を電気量に変換し，デジタルオシ ロスコープによって電流，電圧と共に同時に取り込み，そ の後コンピュータにより解析を行った。モノクロメータの 入射部分および出射部分のスリットを調節することにより, 測定波長の分解能を設定した。また，放電光を増幅させる ため, 光電子増倍管に増幅回路を接続し，使用した。ここ 


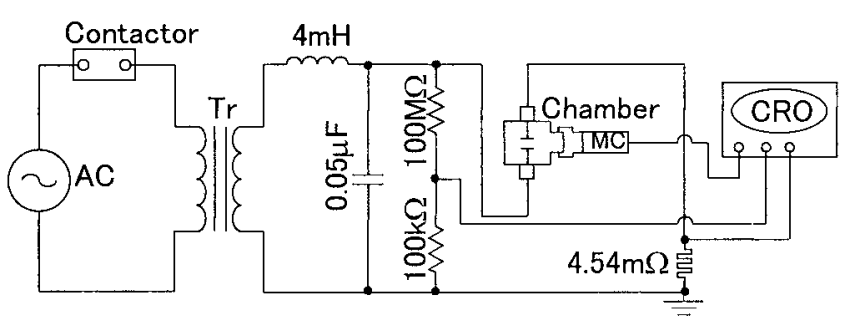

AC: Power supply (100V, 50Hz) Tr: Transformer (1:1) MC: Monochromator CRO: Oscilloscope

図 3 光強度測定回路

Fig. 3. Experimental circuit.



図 4 分光システム

Fig. 4. The system of spectroscopic analyzer.

で，中性光測定の増幅回路のレスポンスタイムは $200 \mathrm{~ns}$ 程 度であり，そして電流裁断時での光の減衰時間が $1 \mu \mathrm{s}$ 程度 であるため，測定可能感度であると考えられる。他方，イ オン光測定の増幅回路のレスポンスタイムは $2.5 \mu \mathrm{s}$ 前後で あるために，電流裁断時に扔ける光強度の減衰速度の大き さを測定することは困難であった。そのため，本件では電 流裁断時での光強度のみ測定を行った。しかし，アーク放 電の変化時間は ms オーダーであるため, 中性拉よびイオ ンのどちらの場合においても，測定可能感度であると考え られる。

$\langle\mathbf{3} \cdot \mathbf{4}\rangle$ 測定方法 中性蒸気の発光測定には干渉フィ ル夕を用いて特定の荷電粒子のみからの光を通過させて測 定を行った。ここで，測定波長は他の材料の強い波長と無 関係であり，比較的に強い波長を選定した。中性蒸気の波 長の選定には，波長領域として，350 $\mathrm{nm}$ から $600 \mathrm{~nm}$ の範 囲をスペクトル測定器により測定し，決定した。1例とし て, $\mathrm{CuCr}$ 電極の結果を図 5 に示す。また，イオン蒸気の 波長は，文献(6)の結果を参考に選定した。これらの結果 から中性蒸気抢よび 1 価のイオン蒸気波長はそれぞれ表 2 に示すものを使用した。なお，Bi のイオン蒸気波長におい ては，比較的強い波長は確認できなかったために，実験を 行うことは困難であった。

光電子増倍管の出力に高圧直流電源より中性蒸気なら $-500 \mathrm{~V}$ ，イオン蒸気なら $-600 \mathrm{~V}$ の電圧を印加させ実験を 行った。

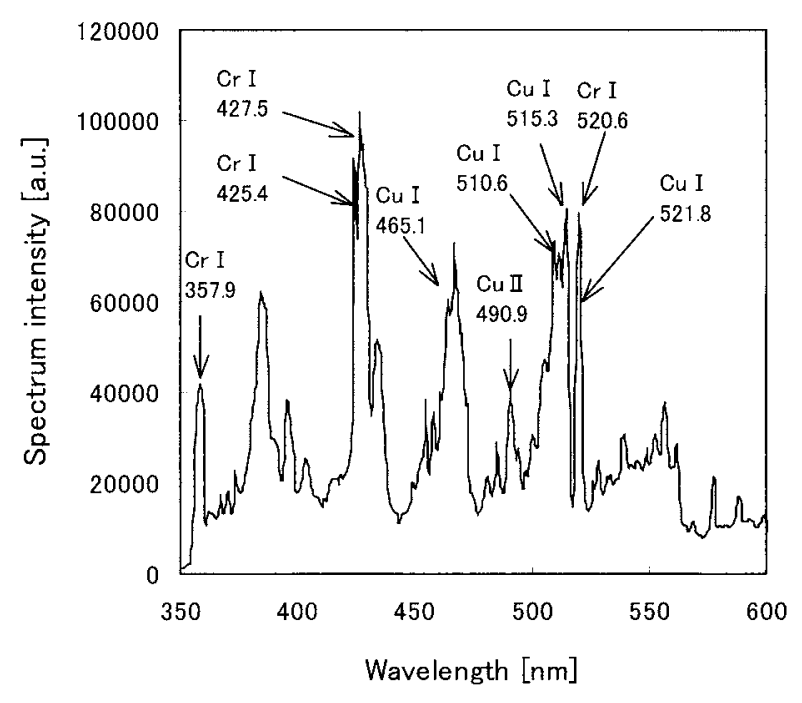

図 5 スペクトル強度分布 $(\mathrm{CuCr})$

Fig. 5. Spectrum intensity distribution of $\mathrm{CuCr}$ Electrode.

表 2 中性蒸気と 1 価イオン蒸気の波長

Table 2. Wavelength of neutral vapor and single-charged ionized vapor.

\begin{tabular}{ccc}
\hline \hline Material & $\begin{array}{c}\text { Neutral vapor } \\
{[\mathrm{nm}]}\end{array}$ & $\begin{array}{c}\text { Ionized vapor } \\
{[\mathrm{nm}]}\end{array}$ \\
\hline $\mathrm{Ag}$ & 546.5 & 243.7 \\
$\mathrm{Bi}$ & 472.3 & - \\
$\mathrm{Cr}$ & 427.5 & 284.4 \\
$\mathrm{Cu}$ & 510.6 & 224.6 \\
$\mathrm{~W}$ & 400.8 & 258.9 \\
\hline
\end{tabular}

$\langle\mathbf{3} \cdot \mathbf{5}\rangle$ 光強度と裁断電流の関係 一般的に, アーク放 電の光強度は電子温度と蒸気密度に関係している。電極材 料の種類よって, 電子温度は放電中にあまり変化せず，又 ペクトル強度はイオン量や蒸気密度に比例すると考えられ ている(7)(8)。

本件において, 分光器を使用し, 各種電極材料の代表的な 中性蒸気抢よびイオン蒸気の発光について, アーク放電時扔 よび電流零点時の光強度とその減衰速度の大きさの調査を 行った。図 6 にアーク放電中に測定できる $\mathrm{CuW}$ 電極にお ける $\mathrm{Cu}$ のイオン波長 $(224.6 \mathrm{~nm})$ の一般的な波形を示す。 図に示すように, 光強度の最大值拉よび光強度の変化速度 の大きさを Umi, dUmi/dt と示す。そして, 図 7 に電流零 点近傍での $\mathrm{CuW}$ 電極に扔ける $\mathrm{Cu}$ の中性波長 $(510.6 \mathrm{~nm})$ の一般的に測定できる波形を示す。図に示すように，電流 裁断時の光強度と光の減衰速度の大きさを $\mathrm{Ucn}, \mathrm{dUcn} / \mathrm{dt}$ と示す。また裁断電流をIcによって示す。電極材料におけ る，電流裁断時の結果を表 3 に示す。

この表において, Material の『Ag in AgWC』とは AgWC 電極に扔ける $\mathrm{Ag}$ 波長の結果を示す。そして, 光強度につ 


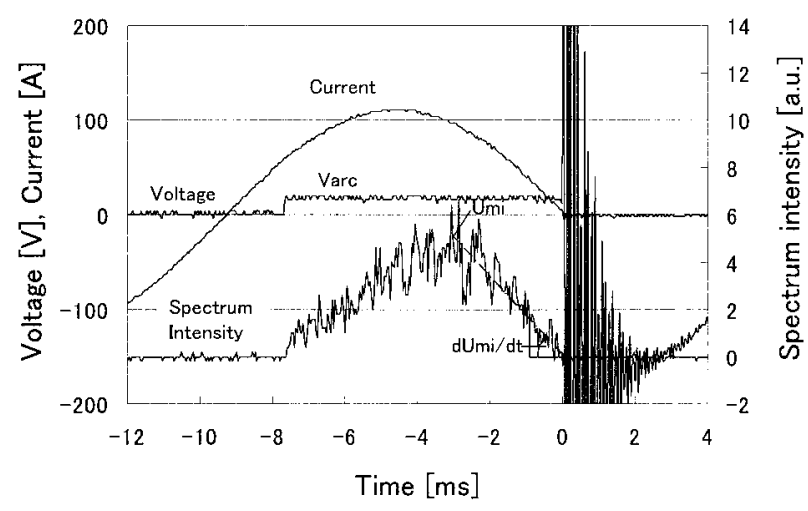

図 6 アーク放電波形 $(\mathrm{Cu}$ in $\mathrm{CuW})$

Fig. 6. Waveform of arc discharge of $\mathrm{Cu}$ single- charged ionized vapor at $\mathrm{CuW}$ electrode.



図 7 電流零点波形 $(\mathrm{Cu}$ in $\mathrm{CuW})$

Fig. 7. Current zero waveform of $\mathrm{Cu}$ neutral vapor at $\mathrm{CuW}$ electrode.

\section{表 3 光強度と減衰速度の大きさ}

Table 3. Spectrum intensity and attenuation speed of intensity.

\begin{tabular}{|c|c|c|c|c|}
\hline Material & Ic $[A]$ & $\begin{array}{l}\text { Ucn } \\
\text { [a.u.] }\end{array}$ & $\begin{array}{l}\mathrm{dUcn} / \mathrm{dt} \\
{[\mathrm{a} . \mathrm{u} . / \mu \mathrm{s}]}\end{array}$ & $\begin{array}{l}\text { Uci } \\
\text { [a.u.] }\end{array}$ \\
\hline $\begin{array}{l}\mathrm{Ag} \text { in } \mathrm{AgWC} \\
W \text { in } \mathrm{AgWC}\end{array}$ & 1.7 & $\begin{array}{l}0.9 \\
0.7\end{array}$ & $\begin{array}{l}1.1 \\
0.7\end{array}$ & $\begin{array}{l}0.1 \\
0.1\end{array}$ \\
\hline $\mathrm{Cu}$ in $\mathrm{CuBi}$ & 4.0 & 2.1 & 1.6 & 0.2 \\
\hline $\begin{array}{l}\mathrm{Cu} \text { in } \mathrm{CuCr} \\
\mathrm{Cr} \text { in } \mathrm{CuCr}\end{array}$ & 4.6 & $\begin{array}{l}2.2 \\
6.8\end{array}$ & $\begin{array}{r}2.3 \\
11.4\end{array}$ & $\begin{array}{l}0.4 \\
0.7\end{array}$ \\
\hline $\begin{array}{l}\mathrm{Cu} \text { in } \mathrm{CuW} \\
\mathrm{W} \text { in } \mathrm{CuW}\end{array}$ & 4.9 & $\begin{array}{l}5.9 \\
3.2\end{array}$ & $\begin{array}{l}6.7 \\
2.9\end{array}$ & $\begin{array}{l}0.4 \\
0.1\end{array}$ \\
\hline $\mathrm{Cu}$ in $\mathrm{Cu}$ & 10.7 & 36.9 & 55.0 & 0.8 \\
\hline
\end{tabular}

Spectrum intensity: Ucn (Neutral), Uci (Ion) Attenuation speed: dUcn/dt (Neutral)

いては相対值を表す単位 [a.u.] で表している。しかしなが ら, 数值は, 図 4 の分光システムの光学系や光電子増倍管の 感度などが中性蒸気の場合およびイオン蒸気の場合におい て，それぞれ同一の条件で観測されたものであり，また，基 準值を同一にしたものである。よって，同様に図 6, 図 7, 図 8 ならびに表 4 拈よび表 6 は中性の場合およびイオンの

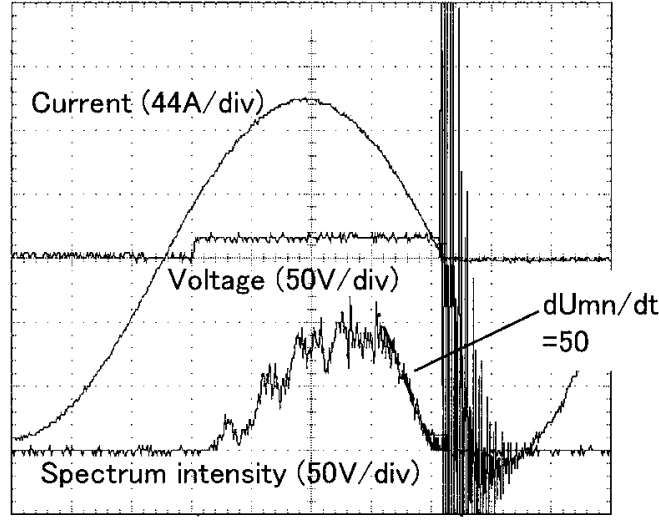

Time $(2 \mathrm{~m} / \mathrm{s})$

(a) $\mathrm{Cu}$ in $\mathrm{CuW}$ (Neutral vapor)

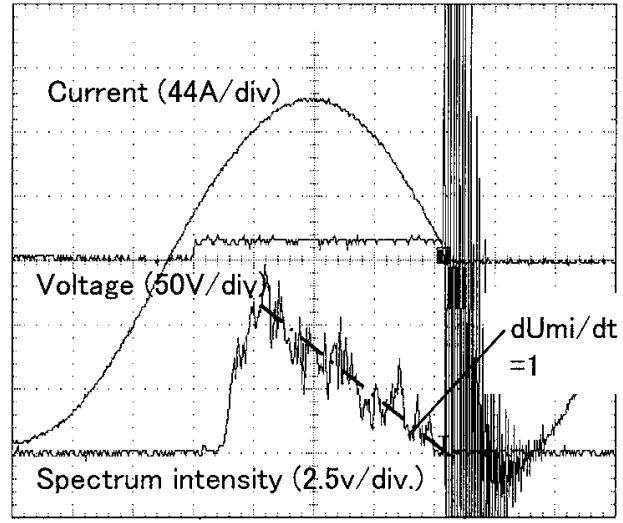

Time $(2 \mathrm{~m} / \mathrm{s})$

(b) $\mathrm{Cu}$ in $\mathrm{CuW}$ (Ionized vapor)

図 8 アーク放電時における変化速度の大きさ

Fig. 8. Intensity recline speed at arc discharge.

表 $4 \mathrm{Cu}$ 合金の光強度の比較

Table 4. Comparison of intensity of $\mathrm{Cu}$ alloy.

\begin{tabular}{|c|c|c|c|c|c|c|c|}
\hline Material & lc $[\mathrm{A}]$ & $\begin{array}{l}\text { Umn } \\
\text { [a.u.] }\end{array}$ & $\begin{array}{l}\mathrm{dUmn} / \mathrm{dt} \\
{[\text { a.u. } / \mathrm{ms}]}\end{array}$ & $\begin{array}{c}1 / \text { in } \\
{[1 / \mathrm{ms}]}\end{array}$ & $\begin{array}{c}\text { Umi } \\
{[\mathbf{a} . u .]}\end{array}$ & $\begin{array}{l}\mathrm{dU} \mathrm{mi} / \mathrm{dt} \\
{[\mathrm{a} . \mathrm{u} . / \mathrm{ms}]}\end{array}$ & $\begin{array}{c}1 / \tau i \\
{[1 / \mathrm{ms}]}\end{array}$ \\
\hline $\mathrm{Cu}$ & 10.7 & 101.8 & 69 & 0.68 & 7.8 & 11 & 1.55 \\
\hline CuW & 4.9 & 90.4 & 52 & 0.58 & 1.1 & 2 & 1.93 \\
\hline $\mathrm{CuCr}$ & 4.6 & 42.7 & 16 & 0.38 & 4.6 & 12 & 2.64 \\
\hline $\mathrm{CuBi}$ & 4.0 & 40.5 & 7 & 0.18 & 6.5 & 17 & 2.77 \\
\hline
\end{tabular}

Intensity: Umn (Neutral), Umi(Ion)

Attenuation speed: $\mathrm{dUmn} / \mathrm{dt}$ (Neutral), $\mathrm{dUmi} / \mathrm{dt}$ $1 / \tau \mathrm{n}=1 / \mathrm{Umn} \times \mathrm{dUmn} / \mathrm{dt}$ $1 / \tau \mathrm{i}=1 / \mathrm{Umi} \times \mathrm{dUmi} / \mathrm{dt}$

場合において，相互に大小関係を比較することができる。 光強度の変化速度の大きさに関しても同様である。また, $\mathrm{CuBi}$ 電極において $\mathrm{Bi}$ の含有量がわずかであるために, Bi 金属の中性蒸気およびイオン蒸気の光強度の測定は困難と された。

〈3.5・1 $\quad \mathrm{Cu}$ 合金の光強度の比較 $\mathrm{Cu}$ 金属を含む $\mathrm{Cu}$, $\mathrm{CuCr}, \mathrm{CuW}$ および $\mathrm{CuBi}$ の 4 種類の電極について, $\mathrm{Cu}$ (中 
表 5 添加金属の物理定数

Table 5. Physical contact of additional metal.

\begin{tabular}{ccc}
\hline \hline Material & Boiling point $[\mathrm{K}]$ & $\mathrm{K}[\mathrm{W} / \mathrm{m} \times \mathrm{K}]$ \\
\hline $\mathrm{Cu}$ & 2,845 & 394.0 \\
$\mathrm{~W}$ & 5,828 & 167.0 \\
$\mathrm{Cr}$ & 2,945 & 91.3 \\
$\mathrm{Bi}$ & 1,837 & 8.0 \\
\hline
\end{tabular}

$\mathrm{K}$ : Thermal conductivity at $297^{\circ}$

性蒸気波長 $510.6 \mathrm{~nm}$ ，イオン蒸気波長 $224.6 \mathrm{~nm}$ ）の光強度 について調査した。アーク放電中の $\mathrm{CuW}$ 電極に扔ける $\mathrm{Cu}$ の中性蒸気㧍よびイオン蒸気のスペクトル強度の実測波形 を図 8 に示す。図からも明らかなように，変化速度の大き さ $\mathrm{dUmn} / \mathrm{dt}$ 㧍よび $\mathrm{dUmi} / \mathrm{dt}$ は中性の場合とイオンの場合 とでは 50 と 1 のように大きな差を確認することができる。 各種電極に打ける中性蒸気抢よびイオン蒸気の光強度の最 大值 $(\mathrm{Umn}, \mathrm{Umi})$, 光強度の変化速度の大きさ $(\mathrm{dUmn} / \mathrm{dt}$, $\mathrm{dUmi} / \mathrm{dt}$ ) 㧍よび裁断電流（Ic）の結果を表 4 に示す。表か ら明らかなように, 光強度の最大值は中性蒸気の場合 $\mathrm{Cu}$, $\mathrm{CuW}, \mathrm{CuCr}$ 㧍よび $\mathrm{CuBi}$ の順に減少を示し, 裁断電流もま た光強度の変化速度の大きさと同じ順に減少を示した。し かし，イオン蒸気は中性蒸気とは異なった傾向を示し，1/ $\mathrm{i}$ は $\mathrm{Cu}, \mathrm{CuW}, \mathrm{CuCr}$ および $\mathrm{CuBi}$ の順に増加した。

この中性蒸気の現象については, 次のように考えられる。 表 4 に示すように, $\mathrm{Cu}$ 電極において，Umn は一番大きい ことから，放電期間中で一時的に $\mathrm{Cu}$ の蒸気量が増大され る。しかし, dUmn/dt もまた大きかったため, 光強度の時 定数 $(\tau \mathrm{n})$ は小さくなり, 短時間でアークを維持するため の蒸気量が不足することにより, 結果的に電流裁断が早く 生じた。

$\mathrm{Cu}$ 金属に他の金属を添加することにより，生成された合 金は，その複合した金属が表 5 に示すように(9)(10)，低沸点 の金属（Bi）であるなら，蒸気発生能力が増大する。また 高沸点㧍よび低熱伝導率の金属 $(\mathrm{Cr}, \mathrm{W})$ なら熱が伝わり にくく, 熱が局所的に集中し, 蒸発しやすい $\mathrm{Cu}$ 部分が蒸 発したと考えられる。このことから $\mathrm{Cu}$ 電極に比べ，どの 合金電極も蒸気量が多いために, 裁断電流值が小さくなっ たと考えられる。

$\langle\mathbf{3 \cdot 5 \cdot 2 \rangle}$ SI の光強度, dUcn/dt および lc の関係 真 空アーク放電中に生成されたプラズマの線スペクトル強度 についてスペクトル測定器を用いて実験を行った。この装 置において, $350 \mathrm{~nm} \sim 950 \mathrm{~nm}$ 波長の発光スペクトル強度の 時間積分值を同時に観測し，各種電極について，同じ条件に 対する波長の発光スペクトル強度の総量を調査した。その 結果を図 9 および数值化した結果を表 6 に示す。この表に

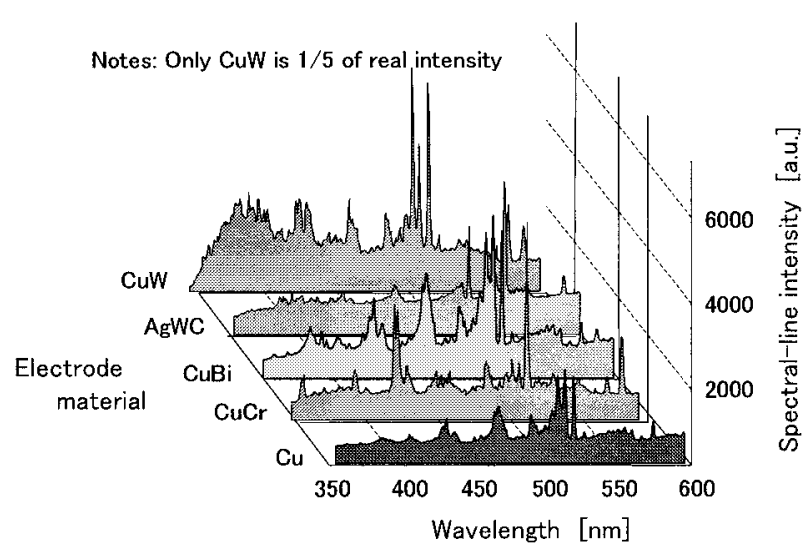

Notes: Only CuW is $1 / / 5$ real intensity

図 9 真空アーク中のスペクトル強度分布

Fig. 9. Spectrum intensity distribution of a vacuum arc.

表 6 裁断電流と光強度の関係

Table 6. Relationship of intensity and chopping current.

\begin{tabular}{crrr}
\hline \hline Material & Ic (A) & SI (a.u.) & \multicolumn{1}{c}{$\begin{array}{l}\mathrm{dUcn} / \mathrm{dt} \\
\text { (a.u./ } \mu \mathrm{s})\end{array}$} \\
\hline AgWC & 1.7 & 909,407 & 0.1 \\
$\mathrm{CuBi}$ & 4.0 & 851,332 & 1.6 \\
$\mathrm{CuW}$ & 4.6 & $4,326,265$ & 2.3 \\
$\mathrm{CuCr}$ & 4.9 & 749,903 & 6.7 \\
$\mathrm{Cu}$ & 10.7 & 674,994 & 55.0 \\
\hline
\end{tabular}

おいて, 各種電極の $\mathrm{dUcn} / \mathrm{dt}$ の結果は表 3 の結果と同様で ある。な㧍，結果が 2 種類の場合 $(\mathrm{AgWC}, \mathrm{CuCr}, \mathrm{CuW})$ は次のように考えた。例えば, $\mathrm{CuW}$ 電極は $\mathrm{W}$ の特に高い 沸点抢よび同じ温度に対する低い蒸気圧から, 電流が零に 近づいて，W の蒸発は非常に小さくなり，無視することが できる。これは $\mathrm{Cu}$ の光強度減衰速度が裁断に影響し, さ らに $\mathrm{AgWC}$ 電極に扔いても同様と考えられる。

表 6 に示すように, $\mathrm{Cu}$ 電極材料において, 電流裁断時の 中性蒸気の減衰速度の大きさ $(\mathrm{dUcn} / \mathrm{dt})$ は最も早いことか ら，プラズマを維持している金属蒸気が早くに拡散される ため, 裁断され電流值が大きくなったと考えられる。中性 の減衰速度の大きさが, この傾向を決めていることについ ては, 今後の課題とする。

$\mathrm{CuW}$ を除いて, SI は AgWC, $\mathrm{CuBi}, \mathrm{CuCr}$ および $\mathrm{Cu}$ の順 に減少し, $\mathrm{dUcn} / \mathrm{dt}$ は同じ順で増加する。Ic もまた $\mathrm{AgWC}$,

$\mathrm{CuBi}, \mathrm{CuCr}$ ，㧍よび $\mathrm{Cu}$ の同じ順に増加する。

$\mathrm{CuW}$ の SI が非常に大きいことについては, 今後の実験 により検討を行いたいと思う。

光強度Ucn およびUci の測定を行った。両者とも同じ電 極では，材料ごとに值が大きく異なるため，裁断電流と関 連づけることは困難と思われる。 


\section{4. まとめ}

電極ごとの不安定開始電流值, 裁断電流值, アーク電圧, 振動電圧最大值および再起電圧最大值の測定を行った。ま た光強度測定において，中性蒸気およびイオン蒸気の光強 度の測定を行い，裁断電流值との関係を調査した。本報告 を要約すると次の通りである。

（1）並列コンデンサの容量を変化させたとき Ib および Varcは一定の值を示した。そして, Ic のみ増加し, Vremax およびVosmax は減少した。

(2) Ib, Ic, Varc, Vremax の大きさは AgWC, CuW, $\mathrm{CuCr}$ および $\mathrm{Cu}$ の順に増加し, Vosmax は $\mathrm{CuW}, \mathrm{AgWC}$, $\mathrm{CuCr}, \mathrm{Cu}$ の順に増加した。

（3）アーク放電の光強度の時定数 $\tau$ は中性蒸気の場合, $\mathrm{Cu}, \mathrm{CuW}, \mathrm{CuCr}$ および $\mathrm{CuBi}$ の順に増加し, イオン蒸気 は同じ順に減少した。

（4）裁断電流 Ic は電流裁断時での中性蒸気のスペクト ル強度減衰速度の大きさ $\mathrm{dUcn} / \mathrm{dt}$ と真空アーク放電中に放 出されたスペクトル強度の総量 SIによって強く影響されて いる。

（5）裁断電流值は単一スペクトル強度 Ucn, Uci では 決まらず，光強度の減衰速度の大きさ $\mathrm{dUcn} / \mathrm{dt}$ が，裁断電 流に対して大きな影響を持っている。 $\mathrm{dUcn} / \mathrm{dt}$ が大きい時 には，材料のプラズマ拡散速度が速く，プラズマを維持す ることができなくなるため，裁断電流は大きくなる。

（6） $\mathrm{CuW}$ を除いて, SI は AgWC, $\mathrm{CuBi}, \mathrm{CuCr}$ およ び $\mathrm{Cu}$ の順で減少し，そして Ic および $\mathrm{dUcn} / \mathrm{dt}$ は同じ順で 増加した。

(平成 17 年 2 月 23 日受付, 平成 17 年 8 月 4 日再受付)

\section{文献}

(1) P.G. Slade: "Advances in Material Development for High Power Vacuum Interrupter Contacts", IEEE Trans. Comp., Packag., Manufact. Technol. A, Vol.17, No.1, pp.96-106 (1994)

(2) R.P.P. Smeets: "Experimental Characterization of Arc Instabilities and Their Effect on Current Chopping in Low-Surge Vacuum Interrupters", IEEE Trans. Plasma Sci., Vol.20, No.4, pp.439-445 (1992)

(3) M. Murano, S. Yanabu, H. Ohashi, H. Ishizuka, and T. Okazaki: "Current Chopping Phenomena in Medium Voltage Circuit Breaker", IEEE Trans. Power Apparatus Syst., Vol. PAS-96, No.1, pp.143-149 (1977)

(4) A. Yamamoto, T. Okutomi, M. Homma, and M. Okawa: "Instability of Vacuum Arc in Ag-Cu Contact alloys", IEEE Trans. Plasma Sci., Vol.21, No.5, pp.463-468 (1993)

(5) C. Ding and S. Yanabu: "Effect of Parallel Circuit Parameters on the Instability of a Low-Current Vacuum Arc", IEEE Trans. Plasma Sci., Vol.31, No.5 (2003)

(6) F.M. Pheips III: M.I.T WAVELENGTH TABLES, Vol.2: Wavelength by Element, pp.800-802, The M.I.T. Pres, Cambrige (1982)

(7) R.P.P. Smeets: "Fluctuations of charged paticle and light emission in vacuum arcs", J. Phys. D: Appl. Phys., Vol.21, pp.301-310 (1988)

(8) O. Morimiya: "Theoretical and Experimental Study of a High- Current Vacuum Arc in a Uniform Axis Magnetic Field", J. Appl. Phys., Vol.71, p.101 (1992)

9) A. Fujishima: Electrochemistry handbook, pp.28-42, Maruzen (2000) (in Japanese)

藤嶋＼cjkstart昭：電気化学便覧, pp.28-42, 丸善 (2000)

10) Y. Waseda: Metal databook, p.14, Maruzen (2004) (in Japanese) 早稲田嘉夫 編：金属データブック,p.14, 丸善 (2004)

山 本 晃 生 (学生員) 1982 年 1 月 28 日生。 2004 年 3 月東

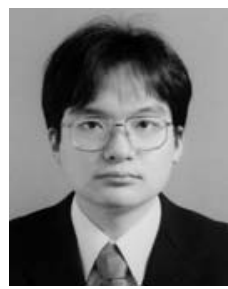
京電機大学工学部電子工学科卒業。同年 4 月東京 電機大学大学院工学研究科電気工学専攻入学, 現 在に至る。主に小電流領域真空アークに関する研 究に従事。

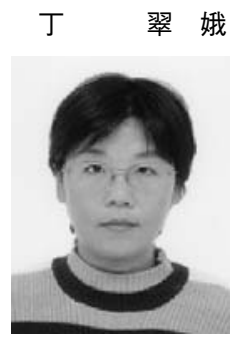

(学生員) 1962 年 11 月 7 日生。1984 年 7 月中 国北京農業工程大学電気工学科卒業。同年 8 月北 京供電局入社。配電系統および変電設備関連の仕 事に従事。2002 年 3 月東京電機大学大学院工学 研究科電気工学専攻修了。2005 年 3 月同大学院 博士課程修了。主に小電流領域真空アークに関す る研究に従事。

Mijit Tursun （学生員） 1973 年 1 月 5 日生。1996 年中国新彊大

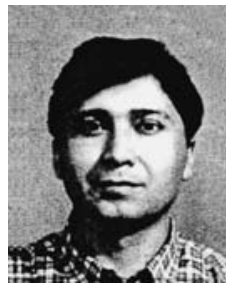
学電気工学科卒業。2004 年東京電機大学大学院 工学研究科電気工学専攻入学, 現在に至る。主に 小電流領域真空アークに関する研究に従事。

柳 父

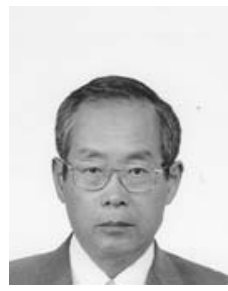

悟（正員） 1941 年 7 月 15 日生。東京大学工学部 電気工学科卒業。同年 4 月（株）東芝入社。1972 年リバプール大学 Ph.D., 工学博士。主として, 高電圧大電流現象の研究および同機器開発に従 事。現在, 東京電機大学教授, Visiting Professor Liverpool。IEEE, IEE Fellow, イギリス Royal Academy of Engineer FREng., Current Zero Club, 日本工学アカデミー会員。 